\title{
PENINGKATAN KEMAMPUAN MEMBACA INTENSIF MELALUI COOPERATIVE LEARNING TIPE STAD KELAS VI SDN 8 PADANG LAWEH
}

\section{IMPROVING THE INTENSIVE READING ABILITY BY COOPERATIVE LEARNING OF THE STAD TYPE IN GRADE VI SDN 8 PADANG LAWEH}

\author{
Tasrial Efendi, Suhardi \\ SD Negeri 8 Padang Laweh Kabupaten Sijunjung Sumatera Barat, Universitas Negeri Yogyakarta \\ etasrial@yahoo.com, suhardiuny@yahoo.com
}

\begin{abstract}
Abstrak
Tujuan penelitian ini adalah untuk meningkatkan proses pembelajaran dan kemampuan membaca intensif siswa kelas VI SDN 8 Padang Laweh dengan pendekatan kooperatif tipe STAD. Penelitian ini menggunakan desain penelitian tindakan kelas. Penelitian dilaksanakan dalam 2 siklus pada semester I tahun ajaran 2013/2014. Teknik pengumpulan data yang digunakan berupa tes, observasi, dokumentasi, dan catatan lapangan. Hasil penelitian menunjukkan bahwa pendekatan cooperative learning tipe STAD dalam pembelajaran membaca intensif terbukti dapat meningkatkan proses dan hasil pembelajaran membaca intensif siswa. Aktivitas siswa dalam proses pembelajaran dari rata-rata 64,33 pada siklus 1 menjadi 80,67 pada siklus 2 dengan kategori sangat baik. Aktivitas guru dalam proses pembelajaran rata-rata 69,00 dengan kategori baik pada siklus 1 menjadi 83,00 pada siklus 2 dengan kategori sangat baik. Kemampuan membaca intensif siswa mengalami peningkatan, yaitu dari rata-rata 66,33 pada siklus 1 menjadi 80,73 pada siklus 2 dengan kategori sangat baik. Jadi pelaksanaan tindakan menggunakan pendekatan cooperative learning tipe STAD telah mencapai indikator keberhasilan dalam penelitian ini, yakni nilai perolehan rata-rata kemampuan membaca intensif mencapai KKM 70,00 dan ketuntasan belajar klasikal mencapai 80\%.
\end{abstract}

Kata kunci: kemampuan membaca intensif, pendekatan cooperative learning tipe STAD

\begin{abstract}
The purpose of this research is to improve the learning process and the intensive reading ability of students of grade VI SDN 8 Padang Laweh through cooperative learning approach of the STAD type. This research used the classroom action research design. This research was done in two cycles in semester 1 of the academic year 2013/2014. The data collection techniques used were test, observation, documentation, and field note. The result shows that the cooperative learning of the STAD type in learning process of intensive reading affects the improvement of the result and process of the intensive reading learning of the students. There is an improvement in students' activity in the learning process with an average score of 64.33 in the first cycle to become 80.67 in the second cycle or in a very good category. The teacher's activity in the learning process has an average score of 69.00 or good category in the first cycle and becomes 83.00 in the second cycle, or in a very good category. The intensive reading ability of the students had an average score of 66.33 in the first cycle and became 80.73 in the second cycle or in a very good category. So, the action from cooperative learning approach of STAD type has reached the success indicator in this research, that is the average score of intensive reading ability of 70.00 and the classical mastery of $80 \%$.
\end{abstract}

Key words: intensive reading ability, learning cooperative of STAD Type 


\section{Pendahuluan}

Perkembangan ilmu pengetahuan dan teknologi menuntut terciptanya masyarakat gemar belajar. Proses belajar yang efektif antara lain melalui membaca. Masyarakat yang gemar membaca memperoleh pengetahuan dan wawasan baru yang akan semakin meningkatkan kecerdasannya sehingga lebih mampu menjawab tantangan hidup di masa-masa mendatang. Perkembangan media cetak maupun elektronik telah menghasilkan berbagai sumber bacaan. Kehidupan saat ini telah dipenuhi oleh sumber bacaan yang sangat beragam. Selain berhadapan dengan bacaan seperti surat kabar, majalah, tabloid, baik yang terbit harian, mingguan, dan bulanan, manusia juga berhadapan dengan banyak buku-buku baru dari berbagai penerbit.

Kemampuan membaca mempunyai kedudukan yang penting dan strategis. Hal ini didasarkan pada kenyataan bahwa pada era reformasi ini, semakin banyak orang yang merasakan manfaat dari kemampuan membaca. Bahkan, membaca telah menjadi kebutuhan dan bagian dari kehidupan sehari-hari. Membaca tidak hanya kemampuan mengenal huruf-huruf yang membangun kata, kemampuan mengenal sederetan kata yang membangun kalimat, atau sekedar kemampuan melafalkannya dengan baik, tetapi lebih luas dari sekedar itu. Membaca menuntut aktivitas mental yang terarah, yang sanggup menangkap dan memahami gagasan-gagasan yang terselubung di balik lambang tertulis tersebut. Karena begitu pentingnya membaca dalam kehidupan seseorang, membaca dapat juga dikatakan sebagai keterampilan atau kecakapan hidup (life skill) dan merupakan salah satu keterampilan berbahasa yang harus dikuasai oleh setiap orang. Hakikat dari suatu keterampilan, cara memperolehnya pasti melalui latihan. Proses membaca melibatkan serangkaian tahapan dan membangun interpretasi setelah mereka membaca dan kemudian menanggapinya (Tompkins, 1995, p.198). Dengan demikian, kemampuan membaca dapat dikembangkan dengan banyak berlatih.

Pembelajaran membaca di Sekolah Dasar mempunyai peran yang penting dalam membantu siswa untuk terampil membaca. Pembelajaran membaca di Sekolah Dasar (SD) bukan hanya bertujuan agar siswa dapt membaca katakata, melainkan juga harus memahami suatu wacana. Saleh $(2006$, p.12) menjelaskan bahwa kemampuan membaca disesuaikan dengan hakikat membaca yang mengacu pada tujuan pembelajaran, bahwa membaca adalah suatu aktivitas untuk menangkap informasi bacaan, baik yang tersurat maupun yang tersirat da-lam bentuk pemahaman bacaan secara literal, inferensial, evaluatif, dan kreatif, dengan memanfaatkan pengalaman belajar membaca. Membaca intensif merupakan lanjutan dari membaca permulaan yang dilaksanakan terutama di kelas I SD. Pada dasarnya membaca intensif diajarkan sejak anak menguasai sistem tulisan, yakni pada siswa kelas III semester I sudah diajarkan membaca intensif ini.

Mengajar dengan strategi membaca intensif diperlukan guru yang memiliki pengetahuan serta memahami hakikat membaca sebagai suatu proses yang sangat kompleks. Menurut Wassid \& Suhendar (2009, p.25) dalam memilih dan menentukan strategi pembelajaran diperlukan pendekatan tertentu. Pendekatan merupakan sudut pandang atau titik tolak untuk memahami seluruh persoalan dalam proses pembelajaran. Sejalan dengan pendapat tersebut, Gulo (2002, p.4) mengemukakan bahwa "Seorang pengajar yang profesional tidak hanya berpikir tentang apa yang akan diajarkan dan bagaimana mengajarkan, tetapi juga tentang siapa yang menerima pelajaran, apa makna belajar bagi siswa, dan kemampuan apa yang ada pada siswa dalam mengikuti pembelajaran".

Sementara itu, berdasarkan hasil pengamatan dan wawancara dengan guru dan siswa kelas VI SDN 8 Padang Laweh, rendahnya kemampuan membaca siswa disebabkan kurang menariknya cara pembelajaran membaca yang dilakukan guru. Berdasarkan pengamatan awal terhadap proses pembelajaran membaca kelas VI SDN 8 Padang Laweh pada tanggal 4 Februari 2013, ditemukan bahwa kemampuan membaca intensif siswa belum mencerminkan tercapainya kompetensi dasar dalam membaca.

Guru dalam pembelajaran membaca intensif, belum menggunakan strategi membaca yang efektif. Kondisi ini terlihat dari gejala yang tampak di lapangan, antara lain: ketika diberi pertanyaan mengenai teks bacaan siswa tidak mampu menjawab pertanyaan yang diberikan oleh guru, pembelajaran membaca dilaksanakan dengan menugasi siswa membaca sendiri, tanpa memberi bimbingan selama proses membaca, biasanya guru memberi pertanyaanpertanyaan pada umumnya bersifat ingatan, guru kurang memberikan kesempatan bagi siswa untuk mengajukan pertanyaan sendiri atau memberikan tanggapan terhadap materi yang dibaca, dalam pembelajaran membaca 
biasanya siswa disuruh bekerja sendiri-sendiri sedangkan teknik diskusi tidak dilakukan.

Berdasarkan wawancara dengan guru kelas VI SDN 8 Padang Laweh pada tanggal 4 Februari 2013 terindikasi bahwa guru hanya mengunakan strategi pembelajaran membaca konvensional yaitu dengan membagikan teks bacaan kemudian siswa disuruh menjawab pertanyaan, kemudian guru hanya menggunakan buku teks sebagai sumber bacaan sehingga informasi yang didapat oleh siswa dalam teks bacaan tidak bertahan lama. Setelah selesai pembelajaran, informasi dalam teks bacaan tidak bisa diinformasikan kepada orang lain sehingga pembelajaran menjadi kurang bermakna. Gejala-gejala di atas disebabkan guru dalam memberikan pembelajaran membaca intensif lebih banyak berpedoman pada buku teks, sehingga pembelajaran membosankan bagi siswa. Dilihat dari fenomena selama ini, proses pembelajaran itu lebih banyak didominasi oleh guru sebagai sumber belajar, sedangkan siswa dijadikan objek untuk menumpahkan isi buku dengan tugas-tugas tanpa perencanaan yang matang. Dalam mengembangkan tujuan pembelajaran, guru lebih banyak menuntut keterampilan berpikir saja. Tidak tergambar keterampilan sosial dan keterampilan lainnya.

Demikian pula halnya dalam pelaksanaan dan evaluasi, lebih banyak keterampilan berpikir yang digunakan. Dalam menggunakan sumber belajar selama ini guru masih banyak berpedoman kepada buku paket dan belum terbiasa mempedomani kurikulum. Kalau diperhatikan lebih lanjut, masih banyak ditemukan guru hanya mengajar untuk menunaikan kewajiban dan mengejar target pelajaran tanpa memperhatikan kartakteristik masing-masing mata pelajaran dan juga karakteristik siswa.

Dari hasil pengamatan dan wawancara dengan guru kelas VI SDN 8 Padang Laweh, diketahui bahwa dalam pembelajaran bahasa Indonesia guru masih mengajar secara konvensional, tidak membiasakan belajar secara berkelompok. Ketika mengajar membaca, guru menugaskan siswa membuka buku paket dan membaca bacaan selanjutnya menjawab pertanyaan yang ada di bawah bacaan tanpa memberi bimbingan. Padahal, dalam proses pembelajaran guru dapat menerapkan pembelajaran yang konstektual dengan melibatkan komponen masyarakat belajar yang dapat dilakukan dengan menerapkan pembelajaran melaui kelompok belajar. Siswa dibagi dalam kelompokkelompok yang anggotanya bersifat heterogen, baik dilihat dari kemampuan belajar dan kecepatan belajarnya. Biarkan dalam kelompoknya mereka saling membelajarkan, yang cepat didorong untuk membantu yang lambat belajar.

Rendahnya keterampilan membaca intensif siswa menjadi permasalahan yang terjadi di SDN 8 Padang Laweh, hal ini disebabkan karena penggunaan pendekatan pembelajaran yang masih belum tepat, sehingga penelitian ini bertujuan untuk meningkatkan proses pembelajaran dan meningkatkan kemampuan membaca intensif siswa dengan pendekatan cooperative learning tipe Student Teams Achievement Divisions (STAD). Hal ini diharapkan bermanfaat baik bagi guru, siswa, sekolah dan peneliti berikutnya.

\section{Metode}

\section{Jenis Penelitian}

Penelitian ini menggunakan penelitian tindakan kelas, dengan menggunakan desain siklus dari Kemmis dan Mc Taggart (1990) yang terdiri dari tiga tahap yaitu: perencanaan, implementasi dan observasi, dan refleksi.

Waktu dan Tempat Penelitian

Penelitian ini dilakukan pada semester I tahun ajaran 2013/2014, yang dilakukan selama bulan November 2013. Hal ini dilakukan sesuai dengan materi yang menjadi fokus penelitian yang ada di kelas VI pada semester I. Lokasi penelitian ini adalah di Sekolah Dasar Negeri 8 padang Laweh, yang terletak di Jorong Bukit Gombak, Nagari Padang Laweh, Kecamatan Koto VII, Kabupaten Sijunjung, Provinsi Sumatera Barat.

\section{Target/Subjek Penelitian}

Target/subjek penelitian adalah siswa kelas VI SDN 8 Padang Laweh yang berjumlah 15 orang, yang terdiri dari 8 siswa laki-laki dan 7 siswa perempuan.

Prosedur

Pada tahap pendahuluan (refleksi awal) kolaborator melakukan observasi langsung tentang keadaan sekolah yang akan dijadikan sebagai tempat penelitian, dengan melihat dokumentasi dan melakukan wawancara dengan guru kelas VI SD Negeri 8 Padang Laweh, Kabupaten Sijunjung yang dilakukan pada tanggal 4 Februari 2013. Hasil observasi dijadikan sebagai acuan bagi penentuan masalah dan pemecahan dari masalah. Data yang diperoleh dibahas bersama dengan guru guru kelas VI 
untuk mencari solusi pemecahan masalah yang ada. Dari hasil pembicaraan dengan guru kelas tersebut disimpulkan bahwa pendekatan mengajar guru kurang menarik minat siswa, sehingga pada penelitian ini diterapkan pendekatan cooperative learning tipe STAD untuk meningkatkan kemampuan membaca intensif siswa.

Pembelajaran dengan pendekatan cooperative learning $\mathrm{STAD}$, siswa saling membantu antara yang satu dengan yang lain dalam kelompoknya. Selanjutnya peneliti bersama kolaborator membuat perencanaan tindakan dan menyusun perangkat yang diperlukan selama tindakan berlangsung yaitu: menyusun skenario tindakan, berupa Rencana Pelaksanaan Pembelajaran (RPP). Skenario pembelajaran berisi langkah-langkah tindakan yang dilakukan oleh guru dan kegiatan siswa ketika guru menerapkan tindakan, menyusun instrumen pengumpulan data penelitian yang terdiri dari instrumen lembar observasi kegiatan guru dan siswa, lembar penilaian, media pembelajaran, dan uraian materi pembelajaran. Observasi dilaksanakan untuk mengamati proses dan dampak. Pada saat tindakan berlangsung, peneliti sebagai observer melakukan observasi dengan menggunakan instrumen yang telah disiapkan. Peneliti melakukan observasi dengan menggunakan lembar observasi untuk memantau pelaksanaan tindakan dan mencatat peristiwa apa saja yang terjadi selama pelaksanaan tindakan di kelas. Fokus dari pengamatan adalah kegiatan siswa dan guru selama pembelajaran berlangsung sesuai dengan skenario pembelajaran. Pada bagian refleksi dilaksanakan analisis data mengenai proses, masalah, dan hambatan yang dijumpai dan dilanjutkan dengan refleksi terhadap dampak pelaksanaan tindakan yang dilaksanakan.

Hasil penelitian menunjukkan bahwa pendekatan cooperative learning tipe STAD dalam pembelajaran membaca intensif terbukti dapat meningkatkan proses dan hasil pembelajaran membaca intensif siswa. Aktivitas siswa dalam proses pembelajaran dari rata-rata 64,33 pada siklus 1 menjadi 80,67 pada siklus 2 dengan kategori sangat baik. Aktivitas guru dalam proses pembelajaran rata-rata 69,00 dengan kategori baik pada siklus 1 menjadi 83,00 pada siklus 2 dengan kategori sangat baik. Kemampuan membaca intensif siswa mengalami peningkatan, yaitu dari rata-rata 66,33 pada siklus 1 menjadi 80,73 pada siklus 2 dengan kategori sangat baik. Ketuntasan belajar klasikal dari $33,33 \%$ di siklus 1 meningkat menjadi $86,67 \%$ di siklus 2. Jadi pelaksanaan tindakan meng- gunakan pendekatan cooperative learning tipe STAD telah mencapai indikator keberhasilan dalam penelitian ini, yakni nilai perolehan ratarata kemampuan membaca intensif mencapai KKM 70,00 dan ketuntasan belajar klasikal mencapai $80 \%$. Pelaksanaan proses pembelajaran baik dari aktivitas guru maupun aktivitas siswa memperoleh rata-rata 80,00 dengan kategori sangat baik.

Data, Intrumen, dan Teknik Pengumpulan Data

Data yang diperoleh menunjukkan rendahnya kemampuan membaca intensif siswa. Data diperoleh melalui observasi langsung di sekolah dengan melakukan wawancara dengan guru kelas VI, dan dengan melihat dokumentasi hasil penilaian siswa. Data dikumpulkan berdasarkan instrumen pengumpulan data.

Teknik pengumpulan data yang digunakan pada penelitian ini adalah teknik tes dan non tes, yang berupa: (1) Tes hasil belajar digunakan untuk mengumpulkan data tentang peningkatan kemampuan membaca intensif siswa. Jenis tes yang digunakan adalah uraian yang berfungsi sebagai tes awal dan tes akhir. (2) Observasi merupakan metode pengumpulan data melalui pengamatan dan pencatatan prilaku subjek penelitian yang dilakukan secara sistematik (Mulyatiningsih, 2011, p.26). Observasi sebagai alat pengumpul data bisa dilaksanakan dalam situasi sebenarnya atau observasi langsung dan bisa pula dalam situasi buatan atau observasi tidak langsung (Sudjana, 2011, p.114). Observasi dilakukan pada saat proses kegiatan itu berlangsung. Observer terlebih dahulu harus menetapkan aspek-aspek apa yang diobservasi dan membuat pedoman agar memudahkan dalam pengisian observasi (Sudjana, 2012, p.85). Dalam penelitian ini aspek yang diamati kegiatan guru dan kegiatan siswa selama proses pembelajaran berlangsung dengan meggunakan lembar observasi atau lembar pengamatan. (3) Dokumentasi merupakan pengambilan gambar, dimana gambar di sini berupa foto-foto pada saat proses pembelajaran membaca intensif berlangsung. Dokumentasi ini berfungsi untuk menjadi bukti mengenai adanya proses kegiatan belajar membaca intensif, dan melalui dokumentasi ini juga dapat menjadi suatu cara mengantisipasi adanya kekeliruan atau kesalahan dalam proses penilaian. (4) Catatan lapangan, merupakan catatan tertulis tentang segala sesuatu berisi hal-hal yang terjadi selama proses pembelajaran yang meliputi aspek pembelajaran di kelas, suasana kelas, 
interaksi antara guru dan siswa, interaksi antar siswa dengan siswa dan sebagainya.

\section{Teknik Analisis Data}

Teknik analisis data pada penelitian ini adalah analisis data kuantitatif dan kualitatif. Menurut Pardjono, dkk (2007, p.53) analisis data pada dasarnya bertujuan mengolah informasi kuantitatif maupun kualitatif. Sementara menurut Muliyatiningsih (2011, p.38) bahwa teknik analisis data ditentukan oleh jenis data dan skala pengukuran. Untuk menganalisis data dalam penelitian ini digunakan analisis kuantitatif. Data kuantitatif adalah informasi yang muncul di lapangan dan memiliki karakteristik yang dapat ditampilkan dalam bentuk angka (Pardjono, dkk, 2007, p.53). Analisis Kuantitatif adalah data yang berhubungan dengan angka-angka atau bilangan, baik yang diperoleh dari hasil pengukuran maupun diperoleh dengan jalan mengubah data kualitatif menjadi data kuantitatif. Data kuantitatif digunakan untuk menganalisis data-data kuantitatif yang diperoleh dalam penelitian. Hasil ini digunakan untuk mengetahui tingkat ketuntasan dan perubahan belajar yang dicapai siswa dalam mempelajari kompetensi membaca yang diajarkan, kemudian digunakan sebagai salah satu pengukur keberhasilan pendekatan cooperative learning STAD sebagai pendekatan pembelajaran yang dapat meningkatkan kompetensi membaca intensif siswa. Untuk menganalisis data kuantitatif hasil belajar berupa tes uraian, maka data yang telah dikumpulkan dianalisis dengan mengikuti langkah-langkah sebagai berikut: (a) Penskoran menggunakan numerical rating scale dengan rentang 1 sampai 5, (Widoyoko, 2013, p.241). (b) Mengubah skor menjadi nilai untuk menentukan nilai hasil belajar dengan rumus:

\section{skor yang diperole!}

skormaksimus X 100. (Suwandi, 2009, p. 127). (c) Memberi tafsiran berupa pengkategorian atas hasil penghitungan. Agar data yang diperoleh dapat bermakna, maka perlu dibuat kategori berdasarkan persentase.

\section{Hasil dan Pembahasan}

\section{Kondisi Lingkungan Sekolah}

SD Negeri 8 Padang Laweh adalah salah satu sekolah yang berada di Kecamatan Koto VII Kabupaten Sijunjung Provinsi Sumatera Barat. Fasilitas sarana dan prasarana yang tersedia di sekolah belum cukup memadai, media pembelajaran yang tersedia juga masih kurang.
Lokasi sekolah berada di tepi jalan raya yang menghubungkan pusat kecamatan dan kabupaten namun aman dan kondusif, berada di lingkungan area yang tidak terlalu padat penduduknya. Sekolah Dasar Negeri 58 Kota Bima seringkali dijadikan sebagai tempat pertemuan guru dan ujian nasional. Di sekitar sekolah tersebut terdapat sebuah sekolah PAUD dan Sekolah Menengah Pertama (SMP). Tepatnya di Jorong Bukit Gombak, Nagari Padang Laweh. Sehingga untuk melanjutkan sekolah ke jenjang berikutnya siswa mayoritas langsung masuk sekolah yang berada di sekitar itu.

\section{Kondisi Siswa}

Pada tahun ajaran 2012/2013, rombongan belajar SD Negeri 58 Kota Bima adalah 12 rombel, dimana setiap tingkat kelas terdapat 2 rombel. Siswa berasal dari latar belakang yang berbeda. Perubahan jumlah siswa tiap tahun ajaran baru tidak mengalami peningkatan yang signifikan karena mengingat jarak sekolah dasar yang satu dengan yang lainnya tidak terlalu jauh.

\section{Kondisi PraTindakan}

Berdasarkan hasil prasurvei terhadap kondisi awal pembelajaran di kelas yang bermasalah tersebut, peneliti dan guru kelas berdiskusi dan melakukan analisis awal berbagai permasalahan yang ada. Diskusi ini dilakukan pada hari Rabu, tanggal 13 November 2013 di ruang kepala sekolah pada pukul 10.00 WIB. Hasil diskusi menunjukkan bahwa permasalahan yang dihadapi dalam pembelajaran membaca yang terkait dengan kemampuan membaca intensif dan proses pembelajaran membaca adalah sebagai berikut. (1) Masih ada siswa kelas VI yang belum bisa membaca dalam hati. (2) Siswa kurang berkonsentrasi, kurangnya minat dan perhatian dalam pembelajaran khusunya membaca intensif. (3) Siswa tampak malas melakukan kegiatan membaca, hal ini terlihat mereka hanya membolak-balik buku saja tanpa melakukan kegiatan membaca dengan serius dan sungguh-sungguh. (4) Dalam pembelajaran membaca guru menggunakan metode ceramah dan penugasan saja. (5) Guru belum pernah menggunakan metode diskusi kelompok karena menurut guru pembelajaran secara individual lebih mudah dilaksanakan. (6) Guru tidak melaksanakan pembelajaran membaca dengan tahap-tahap membaca. (7) Pembelajaran tidak menggunakan media. (8) Hasil postes siswa masih banyak di bawah KKM 70. (9) Menurut guru kelas, hal- 
hal yang kemungkinan besar mempengaruhi keberhasilan pembelajaran membaca intensif adalah penggunaan metode dan media pembelajaran yang kurang tepat. Berdasarkan identifikasi permasalahan dari hasil observasi kondisi awal, selanjutnya disimpulkan bahwa masalah besar yang terjadi dalam pembelajaran tersebut adalah penggunaan metode/pendekatan pembelajaran yang tidak tepat, sehingga mengakibatkan minat, dan aktivitas siswa serta proses pembelajaran yang belum optimal di kelas yang sekaligus dapat mempengaruhi kemampuan membaca intensif siswa. Dengan demikian, penggunaan metode pembelajaran perlu mendapatkan penanganan sebagai upaya pemecahan masalah dengan memberikan tindakan dalam proses pembelajaran Bahasa Indonesia, khususnya membaca intensif.

Ada lima hal yang menjadi pusat perhatian dalam penelitian tindakan ini, yakni: (1) penggunaan pendekatan cooperative learning tipe STAD, (2) aktivitas guru dalam proses pembel-ajaran dengan pendekatan cooperative learning tipe STAD, (3) aktivitas siswa dalam proses pembelajaran dengan pendekatan cooperative learning tipe $\mathrm{STAD}$, (4) kemampuan membaca intensif siswa, dan (5) manajemen kelas.

\section{Pelaksanaan Siklus I}

Rencana Pelaksanaan Pembelajaran (RPP) yang dirancang pada siklus 1 ini digunakan untuk 2 kali pertemuan dengan jumlah jam 4 jam pembelajaran. Pertemuan pertama yaitu pada hari Jumat, 22 November 2013 jam pertama (pukul 07.30-08.40). Pertemuan kedua pada hari Sabtu, tanggal 23 November 2013 pada jam pertama (pukul 07.30-08.40) dengan tindakan kedua. Materi pertama pada pertemuan pertama adalah membaca teks bacaan yang berjudul "Manfaat Bambu", menentukan ide pokok paragraf, dan menuliskan pokok-pokok informasi dalam beberapa kalimat.

Adapun deskripsi proses pelaksanaan tindakan dalam siklus 1 adalah sebagai berikut.

\section{Penggunaan Pendekatan Cooperative Learning Tipe STAD}

Pendekatan cooperative learning tipe STAD yang digunakan dalam pembelajaran membaca intensif sudah cukup baik dalam meningkatkan proses pembelajaran dan kemampuan membaca siswa, meski peningkatan yang terjadi belum sesuai dengan yang diharapkan. Guru membagi siswa ke dalam 4 kelompok secara heterogen yang tingkat kemampuan dan jenis kelaminnya berbeda sesuai dengan yang telah direncanakan sebelumnya. Masing-masing kelompok terdiri dari 4 orang, kecuali kelompok 1 yang anggotanya hanya 3 orang. Siswa ditugaskan untuk membaca dalam hati teks yang telah dibagikan pada masing-masing kelompok. Kemudian siswa bekerja sama dalam kelompoknya untuk mengerjakan lembaran kerja. Siswa yang kemampuannya tinggi membantu siswa yang berkemampuan rendah dalam kelompoknya. Guru berkeliling kelas untuk memantau kegiatan siswa dalam kelompoknya masing-masing. Dalam kerja kelompok ini siswa membutuhkan waktu yang cukup lama. Saat bekerja dalam kelompok, terlihat beberapa siswa masih malu-malu untuk bekerjasama karena dalam satu kelompok digabungkan antara siswa laki-laki dan perempuan. Hal ini terjadi karena guru jarang melakukan pembelajaran dalam kelompok. Di samping itu, terlihat juga kelompok yang sangat aktif dan ada kelompok yang pasif.

\section{Aktivitas Guru dalam Proses Pembelajaran}

Pada pertemuan pertama, proses pembelajaran menyangkut aktivitas guru sudah mengalami perubahan, sudah mengalami sedikit peningkatan dari sebelum adanya tindakan. Aktivitas guru dalam pembelajaran menyangkut tiga hal pokok, yaitu kegiatan awal, kegiatan inti dan kegiatan akhir atau penutup. Guru melaksanakan pembelajaran sudah mengikuti langkah-langkah yang terdapat di dalam Rencana Pelaksanaan Pembelajaran (RPP), yaitu tahap prabaca, tahap saat baca, dan tahap pascabaca. Namun, aktivitas guru masih perlu ditingkatkan lagi. Kegiatan awal (prabaca) pada pertemuan pertama yang dilakukan guru adalah memberikan tes awal kepada siswa. Siswa diberikan bacaan dan disuruh untuk membaca dan kemudian menjawab pertanyaan yang telah disipkan. Setelah memberikan tes awal guru menyampaikan tujuan pelajaran dan tugas-tugas belajar yang harus dikerjakan siswa. Selanjutnya guru membangkitkan skemata siswa dengan memperagakan gambar beberapa benda yang terbuat dari bambu. Fokusnya adalah untuk membangkitkan skemata siswa dan untuk menginterpretasi gambar yang diamati. Semua siswa dengan serius memperhatikan gambar tersebut. Siswa kelihatan antusias dan gembira. Pada kegiatan inti pembelajaran (tahap saat baca), aktivitas guru juga sudah cukup baik. Pada awalnya guru menyajikan konsep tentang 
gagasan utama, dan cara menemukan informasiinformasi yang ada pada sebuah bacaan. Pendekatan cooperative learning tipe STAD dilakukan guru dengan membagi siswa ke dalam empat kelompok. Siswa diberikan bacaan dalam kelompok masing-masing. Semua siswa kelihatan aktif dan konsentrasi membaca. Kemudian guru menugaskan siswa dalam kelompoknya untuk mengerjakan LKS pada kelompok masing-masing. Siswa berdiskusi dalam kelompoknya membahas tugas pada LKS Guru berkeliling kelas mengontrol kegiatan diskusi siswa, dan sesekali memberikan kesempatan kepada siswa untuk bertanya jika ada hal-hal yang mereka tidak pahami. Bagian akhir kegiatan pembelajaran (penutup) pada pertemuan pertama guru mengumpulkan hasil diskusi kelompok siswa. Kemudian guru memberikan catatan singkat kepada siswa mengenai ide pokok/ gagasan utama sebuah paragraf.

Kegiatan pembelajaran pada pertemuan pertama ini terkesan agak tergesa-gesa karena guru khawatir waktu yang digunakan tidak sesuai dengan yang telah direncanakan sebelumnya. Pemberian tindakan dilaksanakan pada pertemuan kedua. Pada kegiatan awal, guru membangkitkan skemata siswa dengan menanyakan pelajaran Bahasa Indoneaia pada pertemuan sebelumnya. Pada kegiatan inti, guru kembali menugaskan siswa untuk duduk dalam kelompok masing-masing. Kemudian guru menugaskan perwakilan masing-masing kelompok untuk melaporkan hasil diskusi mereka di depan kelas, kelompok lain diminta menanggapi hasil diskusi kelompok yang ditampilkan. Guru berusaha menyamakan jawaban dengan cara menugasi kelompok secara bergiliran membaca paragraf yang sedang dibahas dan membicarakan isinya untuk memantapkan jawaban. Setelah semua kelompok menampilkan hasil diskusinya di depan kelas, guru memberikan hadiah sebagai penghargaan bagi kelompok yang terbaik.

Pada kegiatan akhir pembelajaran, guru menyimpulkan hasil diskusi kelompok dan kemudian memberikan tes akhir kepada siswa untuk mengetahui sejauh mana kemampuan siswa dalam membaca intensif. Siswa mengerjakan tes akhir secara individu. Berdasarkan deskripsi tersebut, secara umum aktivitas guru dalam proses pembelajaran pada siklus 1 yang diamati dalam dua kali pertemuan ini sudah cukup baik, baik dari kegiatan awal, kegiatan inti, maupun dalam kegiatan akhir (penutup). Perolehan skor rata-rata aktivitas guru adalah
69,00 dengan kategori baik. Perolehan skor ini belum sesuai dengan harapan. Aktivitas guru dalam proses pembelajaran diharapkan mencapai skor rata-rata $\geq 80,00$ dengan kategori sangat baik, jadi perlu ditingkatkan lagi pada siklus berikutnya.

\section{Aktivitas Siswa dalam Proses Pembelajaran}

Aktivitas siswa pada proses pembelajaran membaca intensif yang diamati adalah pada tahap prabaca, saat baca, dan tahap pascabaca. Peningkatan aktivitas siswa dalam proses pembelajaran membaca intensif sudah tampak pada awal pertemuan pertama. Meskipun peningkatan yang terjadi masih belum maksimal. Perhatian dan minat siswa dalam pembelajaran bercerita sudah cukup baik. Peragaan gambar pada awal pembelajaran sudah mampu menarik minat dan perhatian siswa pada kegiatan pembelajaran. Siswa aktif membicarakan dan menanggapi gambar yang ditampilkan oleh guru. Pada kegiatan inti pembelajaran, siswa juga terlihat aktif dan semangat mengerjakan LKS dalam kelompok masing-masing. Mereka saling bekerja sama untuk menyelesaikan tugas pada LKS dengan sebaik mungkin. Begitu juga pada pertemuan kedua, perwakilan kelompok menyampaikan hasil diskusinya di depan kelas, dan kelompok lain menaggapi hasil kelompok yang disajikan. Di sini juga terlihat peningkatan keaktifan, konsentrasi, kerja sama dan komunikasi siswa dalam kegitan pembelajaran membaca intensif. Sampai pada tahap akhir pembelajaran, terlihat siswa konsentrasi mengerjakan latihan secara individual.

Secara umum rata-rata aktivitas siswa dalam proses pembelajaran berada pada kategori baik, yakni 64,67. Secara individu, terdapat 2 siswa yang memperoleh rata-rata dengan kategori sangat baik, 5 orang siswa yang memperoleh rata-rata dengan kategori baik (nilai ratarata aktivitas berada pada rentang $\geq 60-80$ ). Hal ini sangat perlu ditingkatkan lagi sehingga $80 \%$ siswa memperoleh rata-rata sangat baik dan nilai rata-rata aktivitas siswa berada pada kategori sangat baik dengan skor rata-rata $\geq$ 80,00 .

\section{Kemampuan Membaca Intensif Siswa}

Penilaian kemampuan membaca intensif siswa dilaksanakan pada akhir siklus. Tes yang diberikan adalah tes uraian sebanyak 10 soal yang diberikan secara individual. Kemampuan membaca intensif siswa pada siklus 1 ini baru menunjukkan sedikit peningkatan dari sebelum 
menggunakan tindakan. Beberapa siswa (lima orang) sudah mampu membaca intensif dengan baik yang dibuktikan dengan hasil tes akhir baik. Hal ini dapat dilihat dari perolehan skor rata-rata yang mereka peroleh berada $\geq$ pada KKM 70,00. Mereka sudah mampu memahami isi bacaan dengan baik, menentukan ide pokok paragraf, dan menemukan informasi-informasi penting pada sebuah wacana. Sebagian besar siswa masih perlu peningkatan untuk mencapai ketuntasan yang telah ditetapkan.

Dari hasil tes akhir yang diberikan, mereka masih sulit untuk memahami isi bacaan, belum bisa menentukan ide pokok paragraf dengan baik, dan tidak maksimal dalam menemukan informasi-informasi pada sebuah bacaan. Beberapa diantaranya masih sangat kesulitan dalam mengerjakan tes akhir, karena terbiasa lambat dalam bekerja. Perolehan skor rata-rata kemampuan membaca intensif siswa berada pada kategori baik, yakni 66,33. Hal ini belum sesuai dengan indikator keberhasilan yang telah ditetapkan dalam penelitian ini, yaitu 70,00. Namun jika dibandingkan dengan tes awal sudah mengalami peningkatan, dimana rata-rata tes awal 57,40. Secara individual masih banyak siswa yang belum mencapai ketuntasan, yakni sebanyak 10 siswa atau sebesar $66,67 \%$, diharapkan $80 \%$ siswa tuntas dalam membaca intensif.

Jika diperhatikan dari hasil tes akhir siswa pada siklus 1 , hampir semua indikator pada pembelajaran membaca ini perlu mendapat perhatian khusus, dan perlu ditingkatkan lagi pada siklus berikutnya. Hal ini terlihat dengan adanya siswa yang belum biasa memahami isi bacaan dengan baik, ada yang belum bisa menentukan ide pokok paragraf, dan juga ada yang belim bisa menemukan informasi-informasi pada sebuah bacaan. Diharapkan kemampuan membaca intensif siswa meningkat pada siklus 2.

\section{Manajemen Kelas}

Manajemen kelas dalam pembelajaran membaca intensif dengan pendektan cooperative learning tipe STAD ini menyangkut alokasi waktu, variasi pembelajaran, dan penanganan terhadap siswa yang pasif dalam pembelajaran. Manajemen kelas pada siklus 1 ini perlu untuk ditingkatkan lagi. Guru masih belum dapat mengelola waktu pembelajaran dengan baik. Banyak waktu dihabiskan untuk menertibkan siswa, mengatur tempat duduk, menampilkan hasil diskusi, dan mengerjakan tes. Variasi yang dilakukan guru dalam proses pembelajaran sudah baik, siswa tidak hanya belajar secara individual, namun sudah dibentuk kelompok sesuai dengan pendekatan cooperative learning tipe STAD. Guru masih belum dapat memotivasi beberapa siswa yang bersikap pasif, dan tidak mau tampil dalam bercerita. Untuk ini, guru perlu mencari solusi yang tepat agar siswa yang bermasalah dapat ditangani, sehingga mereka dapat mengikuti teman-teman yang lainnya.

\section{Pelaksanaan Siklus II}

Pelaksanaan tindakan dan observasi untuk siklus 2 dilaksanakan dalam 1 pertemuan (3 jam pembelajaran). Tindakan diberikan pada hari Selasa tanggal 26 November 2013 pukul 07.30-09.15. Deskripsi selengkapnya untuk pelaksanaan tindakan siklus 2 ini akan disampaikan sebagai berikut.

\section{Penggunaan Pendekatan Cooperative Learning Tipe STAD}

Pada siklus 2 ini, penggunaan pendekatan cooperative learning tipe STAD sudah lebih efektif dari pada siklus sebelumnya. Sebelum menugaskan siswa untuk duduk dalam kelompok, guru lebih memotivasi siswa untuk bekerja sama lebih baik lagi dalam kelompok. Guru membagi siswa ke dalam 4 kelompok secara heterogen yang tingkat kemampuan dan jenis kelaminnya berbeda sesuai dengan yang telah direncanakan sebelumnya. Masing-masing kelompok terdiri dari 4 orang, kecuali kelompok 1 yang anggotanya 3 orang. Anggota kelompok pada siklus 2 ini sama dengan siklus 1 . Siswa ditugaskan untuk membaca dalam hati teks yang telah dibagikan pada masing-masing kelompok. Kemudian siswa bekerja sama dalam kelompoknya untuk mengerjakan lembaran kerja. Siswa yang kemampuannya tinggi membantu siswa yang berkemampuan rendah dalam kelompoknya. Guru berkeliling kelas untuk memantau kegiatan siswa dalam kelompoknya masing-masing. Terkadang guru menanyakan apa ada kelompok yang kurang mengerti dengan tugas yang diberikan, dan mengingatkan waktu untuk bekerja tidak lama agar siswa lebih termotivasi dan fokus dalam bekerja dalam kelompok.

\section{Aktivitas Guru dalam Proses Pembelajaran}

Sebagaimana pada siklus 1, pada siklus 2 ini, aktivitas guru dalam pembelajaran menyangkut tiga hal pokok, yaitu kegiatan awal (prabaca), kegiatan inti (saat baca), dan kegiat- 
an akhir (pasacabaca). Aktivitas guru pada kegiatan awal pada siklus 2 sudah sangat baik. Guru sudah sangat baik dalam mempersiapkan siswa untuk mengikuti pembelajaran. Teks bacaan pada siklus 2 ini adalah "Filateli tetap ada dan menarik". Guru membawa beberapa contoh perangko dan memperagakannya di depan kelas. Siswa terlihat sangat antusias untuk memperhatikan guru, mereka juga terlihat termotivasi untuk mengikuti pembelajaran. Banyak siswa yang bertanya pada kegiatan awal ini, karena bagi sebagian mereka perangko merupakan hal yang baru.

Aktivitas guru pada bagian inti pembelajaran sudah sangat baik. Guru telah menjalankan langkah-langkah pembelajaran sesuai dengan RPP dengan menggunakan pendekatan cooperative learning tipe STAD. Pada awal kegiatan inti, guru membagikan bacaan kepada siswa, dan siswa disuruh untuk mencocokkan interpretasi mereka terhadap bacaan yang telah diberikan. Kemudian guru menjelaskan kembali tentang ide pokok paragraf. Untuk menentukan ide pokok paragraf ini, pertama kali guru meminta siswa untuk menghitung jumlah paragraf yang ada pada bacaan yang telah dibagikan, siswa diminta memberikan nomor pada pargraf masing-masing. Guru kemudian bersama siswa mencari ide pokok pada masing-masing paragraf. Setelah semua siswa paham, kegiatan dilanjutkan dengan menemukan informasiinformasi pada sebuah tekas bacaan. Guru terlihat membimbing siswa agar bisa menemukan informasi-informasi pada sebuah bacaan. Guru melanjutkan pembelajaran dengan membagi siswa ke dalam empat kelompok (kelompok sesuai dengan siklus 1). Siswa ditugaskan mengerjakan LKS pada masing-masing kelompok. Siswa terlihat aktif bekerja dalam kelompok mereka masing-masing. Guru terlihat berkeliling melihat pekerjaan siswa dalam kelompoknya. Suasana kelas terlihat kondusif, aman, dan terkendali. Bagian akhir kegiatan pembelajaran (penutup) dilakukan guru dengan baik. Secara keseluruhan, aktivitas guru pada siklus kedua ini sudah mengalami peningkatan yang cukup tinggi, dengan kategori sangat baik.

Berdasarkan deskripsi tersebut, secara umum aktivitas guru dalam proses pembelajaran pada siklus 2 ini sudah sangat baik, baik dari kegiatan awal, kegiatan inti, maupun dalam kegiatan akhir (penutup). Perolehan skor ratarata aktivitas guru dalam proses pembelajaran membaca intensif adalah 83,00 dengan kategori sangat baik, sesuai dengan yang diharapkan dalam penelitian ini. Peningkatan aktivitas guru dalam pembelajaran dapat dilihat pada tabel berikut.

Tabel 1. Peningkatan Aktivitas Guru dalam Proses Pembelajaran Setiap Siklus

\begin{tabular}{ccc}
\hline Siklus & $\begin{array}{c}\text { Rata-rata } \\
\text { Aktivitas Guru }\end{array}$ & Peningkatan \\
\hline Siklus 1 & 69 & 14 \\
Siklus 2 & 83 & \\
\hline
\end{tabular}

Untuk lebih jelasnya peningkatan aktivitas guru dalam proses pembelajaran ditampilkan dalam grafik sebagai berikut.

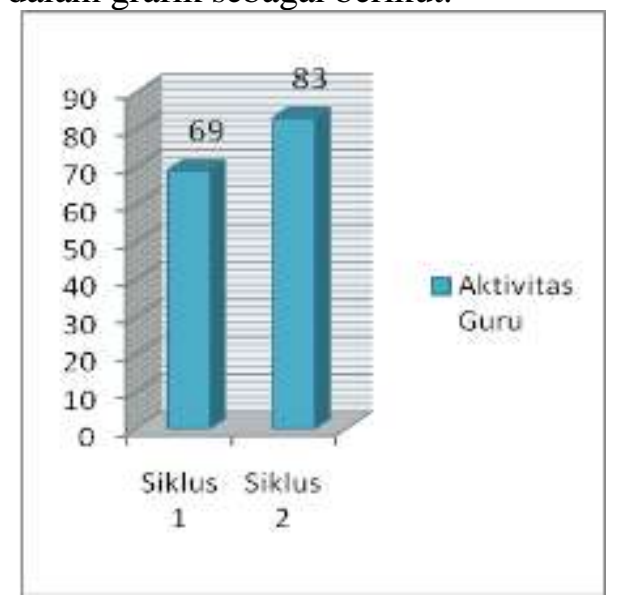

Gambar 1. Peningkatan Aktivitas Guru dalam Pembelajaran

\section{Aktivitas Siswa dalam Proses Pembelajaran}

Aktivitas siswa dalam proses pembelajaran membaca intensif sudah sangat baik sesuai dengan yang diharapkan. Pada awal pertemuan, siswa sudah memperlihatkan minat yang tinggi ketika mengikuti pembelajaran. Perhatian siswa terfokus ketika guru memperagakan beberapa contoh perangko di depan kelas. Mereka terlihat mulai menginterpretasi tentang perangko tersebut. Siswa juga sangat aktif ketika menentukan ide pokok paragraf, dan menemukan informasiinformasi pada sebuah bacaan. Mereka juga aktif bekerja dalam kelompok saat mengerjakan LKS. Tugas yang diberikan oleh guru mereka kerjakan dengan kompak dan bersemangat. Siswa Setiap kelompok kelihatan aktif dan bekerja sama dalam pembelajaran. Dalam kegiatan penutup, siswa juga terlihat sangat aktif. Mereka antusias menanggapi hasil pekerjaan kelompok lain yang disajikan di depan kelas. Begitu juga saat mereka mengerjakan tes akhir, mereka terlihat sangat serius. Secara umum rata-rata aktivitas siswa dalam proses pembelajaran pada siklus 2 ini sudah berada pada kategori sangat baik, yakni 80,66. Aktivitas siswa 
secara individu minimal sudah berada pada kategori baik (berada pada rentang >60-80). Dengan demikian, hasil ini sudah memenuhi indikator keberhasilan dalam penelitian ini.

Peningkatan aktivitas siswa dalam pembelajaran dapat dilihat pada tabel berikut.

Tabel 2. Peningkatan Aktivitas Siswa dalam Proses Pembelajaran

\begin{tabular}{ccc}
\hline Siklus & $\begin{array}{c}\text { Rata-rata } \\
\text { Aktivitas Siswa }\end{array}$ & Peningkatan \\
\hline Siklus 1 & 64,33 & 16,34 \\
Siklus 2 & 80,67 & \\
\hline
\end{tabular}

Untuk lebih jelasnya peningkatan aktivitas siswa dalam proses pembelajaran ditampilkan dalam grafik sebagai berikut ini.

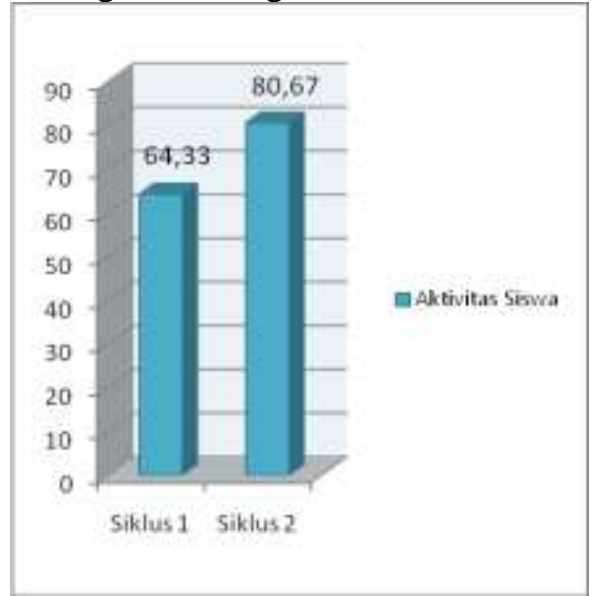

Gambar 2. Peningkatan Aktivitas Guru dalam Pembelajaran

\section{Kemampuan Membaca Intensif Siswa}

Kemampuan membaca intensif siswa pada siklus 2 ini sudah menunjukkan peningkatan yang sangat berarti dari siklus sebelumnya. Peningkatan-peningkatan tersebut dibuktikan dengan hasil tes akhir pada siklus 2. Hasil tes akhir menunjukkan 7 siswa mampu membaca intensif dengan sangat baik dengan skor ratarata $\geq 80(46,66)$, sisanya 7 siswa mampu membaca intensif dengan baik dengan perolehan skor rata-rata berada pada rentang $\geq 60-80$. Sedangkan 1 orang siswa mampu membaca pada kategori cukup, ia memperoleh nilai akhir 55, dan masih di bawah KKM. Walaupun masih ada siswa yang belum mencapai KKM 70, namun penelitian ini sudah dikatakan berhasil karena persentase siswa yang tuntas dalam membaca intensif telah lebih dari $80 \%$, yakni $86,67 \%$.

Peningkatan kemampuan membaca siswa siswa dapat dilihat pada tabel berikut.
Tabel 3. Peningkatan Kemampuan Membaca Intensisf Siswa

\begin{tabular}{ccc}
\hline & $\begin{array}{c}\text { Rata-rata Kemampuan } \\
\text { Membaca Intensif Siswa }\end{array}$ & Ket. \\
\hline Tes awal siklus 1 & 57,40 \\
Tes akhir siklus 1 & 66,33 \\
Tes akhir siklus 2 & 80,73 \\
\hline
\end{tabular}

Untuk lebih jelasnya peningkatan kemampuan membaca intensif siswa ditampilkan dalam grafik sebagai berikut ini.

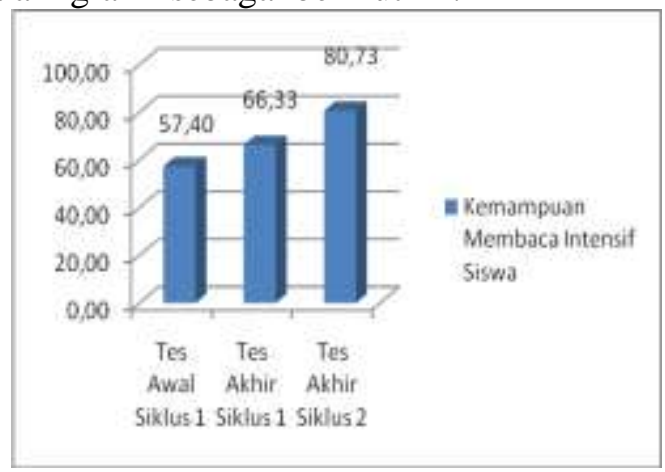

Gambar 3. Peningkatan Kemampuan Membaca Intensif Siswa

\section{Manajemen Kelas}

Manajemen kelas guru pada siklus 2 ini sudah dapat dilaksanakan guru dengan baik. Guru sudah dapat melaksanakan pembelajaran dengan baik sesuai dengan alokasi waktu yang telah ditetapkan di dalam Rencana Pelaksanaan Pembelajaran. Pembelajaran membaca menjadi menarik dan menyenangkan bagi siswa karena guru mengajar dengan berbagai variasi. Guru sudah dapat mengatasi beberapa siswa yang biasanya pasif mengikuti kegiatan pembelajaran dengan selalu melibatkan mereka dengan memberi berbagai pertanyaan. Siswa yang pemalu dan kurang memiliki percaya diri untuk berbicara sudah dapat diatasi oleh guru dengan cara memberikan penguatan berupa pujian.

\section{Simpulan dan Saran}

Simpulan

Penelitian ini merupakan suatu upaya untuk meningkatkan kemampuan membaca intensif siswa kelas VI SDN 8 Padang Laweh dengan pendekatan cooperative learning tipe STAD. Berdasarkan hasil penelitian, analisis data dan pembahasan hasil penelitian pada bab sebelumnya, maka pada bab ini akan diuraikan beberapa kesimpulan sebagai berikut. (1) Pendekatan cooperative learning tipe STAD dapat meningkatkan proses pembelajaran membaca intensif. Hal ini terbukti dengan meningkatnya 
aktivitas siswa dan guru dalam proses pembelajaran. Skor rata-rata aktivitas siswa pada siklus 1 berada pada kategori baik yaitu 64,33. Kemudian pada siklus 2 skornya meningkat menjadi 80,67 yang termasuk dalam kategori sangat baik. Selain meningkatkan aktivitas siswa dalam pembelajaran, pendekatan cooperative learning tipe STAD juga dapat meningkatkan aktivitas guru dalam proses pembelajaran. Hal ini dapat terlihat dari perolehan skor rata-rata aktivitas guru pada siklus 1 hanya sebesar 69,00 termasuk kategori baik. Setelah diberi tindakan pada siklus 2 aktivitas guru meningkat menjadi 83,00 dan termasuk dalam kategori sangat baik. Berdasarkan rata-rata skor yang diperoleh pada siklus II tersebut, aktivitas siswa dan guru dalam proses pembelajaran sudah berhasil karena sesuai dengan indikator keberhasilan yang telah ditetapkan. (2) Pendekatan cooperative learning tipe STAD dapat meningkatkan kemampuan membaca intensif siswa kelas VI SDN $8 \mathrm{~Pa}$ dang Laweh. Hal ini dapat terlihat dari hasil tes siswa, nilai rata-rata kemampuan membaca intensif pada saat tes awal hanya sebesar 57,40 termasuk dalam kategori cukup, kemudian setelah dilakukan tindakan siklus I meningkat menjadi 66,33 termasuk dalam kategori baik, kemudian dilakukan lagi tindakan pada siklus II dan nilai rata-ratanya meningkat lagi menjadi 80,73 dan termasuk dalam kategori sangat baik. Berdasarkan nilai yang diperoleh pada siklus II tersebut, peningkatan kemampuan membaca intensif siswa sudah berhasil karena indikator keberhasilan yang ditetapkan sudah tercapai

Saran

Berdasarkan kesimpulan dan dengan memperhatikan implikasi dari penelitian di atas, maka saran yang dapat disampaikan adalah sebagai berikut. (1) Kepada guru, khususnya guru kelas di SD Negeri 8 Padang Laweh Kabupaten Sijunjung, agar lebih memahami dan merancang pembelajaran membaca khususnya membaca intensif dengan pendekatan cooperative learning tipe STAD agar lebih inovatif, dan berusaha mengimplementasikannya dalam pembelajaran membaca di kelas. Pendekatan cooperative learning tipe STAD ini dapat meningkatkan kemampuan siswa dalam membaca intensif dan dapat pula meningkatkan aktivitas guru dan siswa pada proses pembelajaran sehingga tercapai tujuan pembelajaran yang diinginkan. Oleh karena itu perlu terus dikembangkan secara berkelanjutan dan dapat digunakan pada mata pelajaran yang lain. (2) Kepada Peneliti Selanjutnya, (a) Pada penelitian ini penelitian ditujukan untuk meningkatkan kemampuan membaca intensif dan meningkatkan proses pembelajaran yang menyangkut aktivitas guru dan siswa dengan menggunkan pendekatan cooperative learning tipe STAD. Bagi calon peneliti lainnya dapat melakukan penelitian dengan tujuan lain seperti meningkatkan kreativitas siswa, minat dan motivasi belajar. (b) Penelitian ini dilakukan pada standar kompetensi memahami teks dengan membaca intensif dan membaca sekilas dengan kompetensi dasar menanggapi informasi dari kolom atau rubrik khusus. Kemungkinan untuk diujicobakan pada standar kompetensi dan kompetensi dasar lain dapat dilakukan dengan pertimbangan kesesuaian dan keefektifannya.

\section{Daftar Pustaka}

Gulo, W. (2002). Strategi belajar mengajar. Jakarta: Grasindo

Mulyatiningsih, E. (2011). Riset terapan: bidang pendidikan dan teknik. Yogyakarta: UNY Press.

Pardjono, dkk. ( 2007). Panduan penelitian tindakan kelas. Yogyakarta: Lembaga Penelitian UNY.

Saleh, A. (2006). Pembelajaran bahasa Indonesia yang efektif di sekolah dasar. Jakarta: Depdiknas.

Sudjana, N. (2011). Dasar-dasar proses belajar mengajar. Bandung: Sinar Baru Algesindo.

Sudjana, N. (2012). Penilaian hasil proses belajar mengajar. Bandung: PT Remaja Rosdakarya.

Suwandi, S. ( 2009). Model assesmen dalam pembelajaran. Surakarta: Mata Padi Presindo.

Tompkins, G.E., \& Hoskisson, K. (1995). Language arts: Content and teaching strategies. London: Merril Prentice Hall Inc.

Wassid, I. \& Suhendar, D. (2009). Strategi pembelajaran bahasa. Bandung: Remaja Rosda Karya.

Widoyoko, E. P. (2013). Evaluasi program pembelajaran panduan praktis bagi pendidik dan calon pendidik. Yogyakarta: Pustaka Pelajar. 